\title{
Anthós
}

\section{It's Not What You Do, It's Who You Are: Adjectives as Identity-Conferrers}

\author{
C.B. Rodgers \\ Portland State University
}

Follow this and additional works at: https://pdxscholar.library.pdx.edu/anthos

Part of the Discourse and Text Linguistics Commons Let us know how access to this document benefits you.

\section{Recommended Citation}

Rodgers, C.B. (2012) "It's Not What You Do, It's Who You Are: Adjectives as Identity-Conferrers," Anthós: Vol. 4: Iss. 1, Article 6.

https://doi.org/10.15760/anthos.2012.85

This open access Article is distributed under the terms of the Creative Commons Attribution-NonCommercialShareAlike 4.0 International License (CC BY-NC-SA 4.0). All documents in PDXScholar should meet accessibility standards. If we can make this document more accessible to you, contact our team. 
It's Not What You Do, It’s Who You Are: Adjectives as Identity-Conferrers

\section{C.B. Rodgers}

Portland State University 
My first few weeks living in Portland, I had an interaction with a person I later realized was wearing a sweatshirt emblazoned with the logo for White Aryan Resistance, a neo-Nazi white supremacist organization. As a black woman from the South, I had experienced white supremacist violence first-hand. However, being in such close contact with neo-Nazi skinheads was new, and terrifying--I was incensed, and a bit surprised, to learn that there were open fascists in my new, progressive city. In an attempt to protect myself, I began to study Oregon's history of white supremacy--which included a series of exclusion laws aimed at blacks, among others, drafted and passed in the mid-1800s--and how it informed Portland's history of white supremacist and/or fascist activity--from police officers Craig Ward and Jim Gallaway leaving dead possums on the doorstep of a black-owned business in 1981 to the 1988 murder of Mulugeta Seraw in SE Portland by neo-Nazi skinheads.

I have lived in Portland, and been involved with various politically left groups, for five years. In that time I have seen racist acts (including speech acts-) perpetuated by some members of the community. I have seen other members of that same (ostensibly anti-racist and antioppressive) community minimize, explain away, or otherwise deny the racist nature of those acts through positive assessments of the personalities and identities of the people engaging in them. Such denials are dangerous; they normalize white supremacy and the interpersonal and institutional violence that upholds it through erasure of its existence.

Curiosity about the discursive strategies and methods used to create these positive identity assessments, and how those strategies are linguistically realized, fueled my analysis. So too did outrage at the implication underlying the practice of these strategies and methods: that 
identity construction and evaluation of a person can, or should, be, separated completely from their words and actions.

To see how positive identity assessments are created, I investigated two statements, both released by organizations that can broadly be described as part of Portland's liberal or left community. Each statement responds to assertions that the actions of the organization, or one of its members, provides a platform for anti-Semitic, white supremacist, and/or fascist political organizers to make inroads in Portland. One set of data is a statement from Citybikes, a workerowned cooperative, that was published on Portland IndyMedia, a web-based independent media center; the other is a statement from a Portland community art space, The Variant, that was published on Facebook. The assertions come from Rose City Antifa (RCA, or Antifa), a group that opposes fascist organizing. The following working definition of fascism comes from RCA's website:

RCA recognizes a number of characteristics of fascist movements. Fascism is an ultranationalist ideology that mobilizes around and glorifies a national or perceived racial identity, valuing this identity above other interests (i.e. gender or class). Fascism is marked by its hostility towards Enlightenment values and rationalism, its dehumanization and scapegoating of marginalized or oppressed groups, its use of violence or threats of violence to impose views on others, and its rejection of "effeminate" or "soft" values in favor of "manliness." Antisemitism and racism are primary facets of National Socialism and most other varieties of fascism. Fascism aims at a militarized society, and organizes along military or quasi-military lines, usually with an authoritarian structure revolving around a single, charismatic leader. Fascist groups may have the facade of an efficient and dynamic organization, but in reality, power structures are arbitrary and ruthless. Fascists use anti-elitist rhetoric to appeal to the "common man," coupled with internal elitism and willingness to accept support from existing elites. Fascism glorifies a mythologized past as justification for its present ideological stances, and as a basis for future organization of society. 
The analysis incorporates quantitative and qualitative methods to examine how language is utilized in the construction and assignation of identities. Adjectives, specifically attributive adjectives, are used to construct identities in the texts, and to position those constructed identities within a leftist social and political milieu. The identities constructed, and subsequent positioning of those constructions, function obliquely to refute Antifa's assertions without having to acknowledge the existence of the acts, or grapple with the fascist, white supremacist, and/or antiSemitic nature of the acts.

In June of 2009, RCA issued a statement on Portland Indymedia highlighting the decisions of Tim Calvert, a Citybikes Board member and cooperative-owner, to invite and host white supremacist, anti-Semitic, and fascist speakers Valdas Anelauskus and David Irving (also a convicted Holocaust denier) under the auspices of the Portland 9/11 Truth Alliance, and calling on Citybikes to remove Calvert from the co-operative. In July of 2009, a response was published via the same website by members of Citybikes’ Board of Directors; the response asserted Citybikes’ support of Tim Calvert, and declined to take the action demanded by RCA.

In December of 2010, RCA issued a statement on their website drawing attention to the decision of local metal band Agalloch to invite far-Right Austrian musical project Allerseelen as a supporting group on their West Coast tour. Two days later, as a result of that statement, and pressure from RCA, The Variant canceled Allerseelen's scheduled show. They published a statement explaining their decision to cancel on the Facebook event page that had been created for the show. 
The responses from the two organizations seem at first to differ significantly: Citybikes refused to take the action demanded by Antifa while The Variant did. I conjectured that these respective actions were indicative of the differences in social and political positioning of each organization, and wondered how those positions were established and held through language.

Going along with my conjecture that the actions taken and statements issued by each organization in response to RCA's assertion of problematic behavior was grounded in their selfimage, I decided to investigate how, if at all, the language in each statement created an identity for the involved parties. The two texts that form the data are fairly similar in length, though they adhere to different genre conventions. Citybikes' statement was a letter. The Variant's statement was a status update on the official Facebook page of the art space, and the first comment in the update thread, which was posted one minute later. Both are posted in the persona of The Variant, and I chose to consider the update and the thread together as The Variant's official response.

Citybikes' statement has a total word count of 414; The Variant statement's total word count is 339. I began by identifying the adverbs and adjectives in each statement. I chose to look at these parts of speech first because I was interested in actions and image building. Adverbs modify, among other things, verbs, which are the process or action in a sentence; adjectives modify nouns and describe the nature of people, places, and things. I calculated the ratio of each individual part of speech to the total statement word count, and expressed that ratio as a percentage. Tables 1 and 2 show the total number of words and each part of speech, as well as the ratios, for adverbs and adjectives, respectively. 
Table 1

\begin{tabular}{|l|c|c|c|}
\hline $\begin{array}{l}\text { Organization } \\
\text { responsible for } \\
\text { statement }\end{array}$ & $\begin{array}{c}\text { Total } \\
\text { Number of } \\
\text { Words }\end{array}$ & $\begin{array}{c}\text { Total Number } \\
\text { of Adverbs }\end{array}$ & $\begin{array}{c}\text { Percentage of Words } \\
\text { that are Adverbs } \\
\text { (\%) }\end{array}$ \\
\hline $\begin{array}{l}\text { Citybikes Worker } \\
\text { Collective statement }\end{array}$ & 414 & 9 & 2.2 \\
\hline Variant lab statement & 339 & 8 & 2.4 \\
\hline
\end{tabular}

Table 2

\begin{tabular}{|l|c|c|c|}
\hline $\begin{array}{l}\text { Organization } \\
\text { responsible for } \\
\text { statement }\end{array}$ & $\begin{array}{c}\text { Total } \\
\text { Number } \\
\text { of } \\
\text { Words }\end{array}$ & $\begin{array}{c}\text { Total Number of } \\
\text { Adjectives }\end{array}$ & $\begin{array}{c}\text { Percentage of Words that } \\
\text { are Adjectives (\%) }\end{array}$ \\
\hline $\begin{array}{l}\text { Citybikes Worker } \\
\text { Collective } \\
\text { statement }\end{array}$ & 414 & 37 & 8.9 \\
\hline $\begin{array}{l}\text { Variant lab } \\
\text { statement }\end{array}$ & 339 & 23 & 6.8 \\
\hline
\end{tabular}

The Variant statement had 2.88 times as many adjectives as it did adverbs; the Citybikes

statement had 4.1 times as many adjectives as adverbs. RCA's assertions focused on the actions taken by organizations and individuals, rather than evaluating the inner fundamental nature of the organizations and individuals; I found it interesting that the responses contained relatively few adverbs, and decided to focus on the adjectives.

I compiled an exhaustive list of adjectives for each statement; during the course of that compilation, it became clear to me that most of the adjectives used were attributive. Attributive adjectives describe a property of the head of the noun phrase which they modify. Table 3 shows the ratio of attributive adjectives to total adjectives, again expressed as a percentage. 
Table 3

\begin{tabular}{|l|l|l|l|}
\hline $\begin{array}{l}\text { Organization } \\
\text { responsible for } \\
\text { statement }\end{array}$ & $\begin{array}{l}\text { Total Number of } \\
\text { Adjectives }\end{array}$ & $\begin{array}{c}\text { Number of } \\
\text { Attributive } \\
\text { Adjectives }\end{array}$ & $\begin{array}{l}\text { Percentage of Adjectives } \\
\text { that are Attributive (\%) }\end{array}$ \\
\hline $\begin{array}{l}\text { Citybikes Worker } \\
\text { Collective statement }\end{array}$ & 37 & 25 & 67.6 \\
\hline $\begin{array}{l}\text { Variant Lab } \\
\text { statement }\end{array}$ & 22 & 13 & 59.1 \\
\hline
\end{tabular}

I decided next to qualitatively examine the adjectives in each text in order to see what kind of work they were doing in the text, to whom or what the attributes were being ascribed, and whether certain attributes were more likely to be applied to one entity or another. Though I do some analysis of the work of predicative adjectives (and other linguistics structures), I focus primarily on the attributive adjectives in this analysis, as I think they most directly confer identity onto the individuals, organizations, and entities involved in these data.

To get an idea of the self-image presented by The Variant and Citybikes, I perused their Facebook page, and organizational website, respectively. To get an idea of the role each organization fills in the politically left community, I used the knowledge and experience I have as a member of that community. The Variant is a volunteer-run community art workspace that explicitly includes in its aims fostering an environment that encourages a radical analysis of power; most events are free or sliding-scale, and the space operates in accordance with a policy of anti-oppression. The Variant provides performance and work space for artists, and hosts other events for the community, such as yoga; additionally, it has occasionally hosted talks and panels by local groups engaged in radical political organizing. Conversely, Citybikes is a worker-owned collective, a well-known and well-respected business whose primary purpose is to make money 
by offering a service. Together, the collective nature of the business and the environmental concerns that contribute to its clientèle's desire for the offered services provide Citybikes an image of progressiveness and liberalism, though no specific or official political philosophy undergirds the work they do, or informs how that work is accomplished.

In the Variant statement, attributive adjectives primarily did the work of characterizing the desires, knowledge, and beliefs of the organization and imbuing the organization itself with specific qualities. The first sentence of the statement uses two attributive adjectives to center attention on what the organization finds essential. The adjectives in question are italicized in Excerpt 1.

Excerpt 1

'The Variant would like to explain that it is our primary concern in this matter to maintain a Safer Space policy.'

The goal of a Safer Space policy is to prohibit racist, sexist, homophobic, and ableist speech in particular, and anti-oppressive speech more broadly. This sentence uses adjectives to position the Variant as committed to anti-oppressive work.

Throughout the text, The Variant uses attributive adjectives to describe its character. At various points in the text, members of The Variant create and promote an identity for themselves, and a social positioning through that identity, through the use of both attributive and predicative adjectives. In Excerpt 2, and the rest of the analysis, predicative adjectives are underlined while attributive adjectives are italicized. 
Excerpt 2

'We are a small community space that is dedicated to fostering creative and artistic collaborations, particularly within the anarchist, anti-authoritarian and radical community.'

Through the use of predicate adjectives 'small', 'community' and 'dedicated' The Variant builds an identity for itself and its space; through the use of attributive adjectives, The Variant identifies the community to which it is committed as 'anarchist', 'anti-authoritarian,' and 'radical', and the work that it does in that community as 'creative' and 'artistic'. The adjectives used, both predicative and attributive, develop for The Variant an identity as a space that values collaboration in creativity and art, and as an entity that prefers to do that collaboration in a leftist environment, specifically an anarchist, anti-authoritarian, and radical one.

However, there are other adjectives in The Variant statement that do other work. In Excerpt 3, The Variant expresses skepticism to Antifa's claims and evidence regarding the farRight nature of the politics of the band Allerseelen. The bolded word in Excerpt 3 is an adverb; though generally I chose not to focus on adverbs in this analysis, this token was remarkable enough that it bears mentioning.

\section{Excerpt 3}

'Although there is conflicting information that brings suspicion to the political intentions of Allerseelen, to our knowledge none of the bands lyrics or actions have been overtly fascist or violent, and most of the information and statements attributed to them are arguable. We were appreciative of the initial intervention of Rose City Antifa in alerting us of the potential conflict of interest and their intention to publish an article about the band.' 
In this excerpt, The Variant uses adjectives to acknowledge the receipt of information about the political philosophy and actions of the band ('conflicting information that brings suspicion to the political intentions of Allerseelen) and express appreciation for RCA's choice to share information ('We were appreciative of the initial intervention of Rose City Antifa in alerting us of the potential conflict of interest and their intention to publish an article about the band'), even as it subtly casts doubt on the legitimacy of the information. Note the use of the word 'conflicting' to describe RCA's information, and the use of the word 'potential' to describe the conflict of interest that must result from allowing a far-Right band to play at a radical, anarchist, anti-authoritarian art space.

. The statement also uses predicative adjectives to distance itself from belief in Antifa's claims that Allerseelen's lyrics or actions are fascist or violent ('to our knowledge none of the bands lyrics or actions have been overtly fascist or violent') and to cast doubt on the reliability of the evidence provided by RCA ('and most of the information and statements attributed to them are 'arguable'). Interestingly, the distancing relies on a precise formulation of the nature of the actions as not 'overtly fascist or violent' while paradoxically making a claim of ignorance ('to our knowledge') about the actions. The adjective 'arguable' suggests that Antifa's evidence is dubious. Altogether, this works to defend Allerseelen and subtly challenge RCA's assertions as blown out of proportion, and not well-grounded in fact.

Though The Variant canceled the show, an action in line with its social and political positioning, the language of the response publicizing the cancellation works to position the farRight nature of the group Allerseelen as not out of line with The Variant's anti-authoritarian, 
anarchist, radical philosophy. Though no tension exists between the the Variant's politics and its actions in this case, there is misalignment between the language used to talk about the politics of Allerseelen the band, and the politics espoused by The Variant itself. Ultimately, in their statement, The Variant created for themselves a radical, leftist, anti-authoritarian identity, gained credibility through engaging in action that supported that identity, and then used that created identity and gained credibility to refuse to challenge (and perhaps to render immune to challenge) the politics of a music group spreading far-Right politics and neo-fascist culture.

In the statement from Citybikes, attributive adjectives primarily do the work of producing and imparting identities on three entities: Tim Calvert, Citybikes itself ,and Rose City Antifa. Excerpt 4 shows how the statement provides for Calvert an identity as a political organizer with broad and wide reaching interests, a man who is not afraid of searching out information or discussing topics that might be taboo. Indeed, the attributive adjective 'political' appears four times in the statement; every time it occurs, it references Calvert. Half of those occurrences take place in Excerpt 4.

\section{Excerpt 4}

'Tim is well known in the Cooperative for his years of political organizing and for his political and social points of view on a wide range of topics, some of which appear quite controversial to the casual observer.'

Calvert is also given an identity of open-minded tolerance, especially with regard to the beliefs of Jewish people. Calvert's identity of personal tolerance is composed in tandem with that of Citybikes in excerpt 5. The identification of sexism, racism, and other forms of oppression as 'personal' is notable; I'll speak more about what I think that signifies later. I called the phrase 
'anti-anything-else’ in Excerpt 5 a predicative adjective because it’s coordinated with the adjective anti-Semitic; its use further underscores Citybikes’ assessment of Calvert's tolerance.

\section{Excerpt 5}

'Sexism, racism, and other forms of personal oppression have no place at Citybikes. Tim has always respected the diversity of thought, belief, and religious observance that is to be found here. We have never heard him say anything that could be construed as anti-Semitic, or really anti-anything else, for that matter. Several members of Citybikes' Workers Cooperative are of Jewish heritage and at least one is a religiously observant Jew. None of us has ever felt that Tim did not accept us for our heritage or religious practices.'

In Citybikes’ view, Calvert’s choice to provide a platform for fascist, anti-Semitic, white supremacist speech is not part of his identity. That they do not consider Calvert's actions to be important is evidenced by their complete omission of and refusal to engage with the acts perpetuated by Calvert. Nowhere in the statement do they acknowledge even the existence of the charges put forth by RCA against Calvert; instead, they create a positive identity and personal assessment of Calvert.

Citybikes defines and positions itself as a mature, flexible business organization in which multiple voices are valued and necessary to the proper functioning of that business, as evidenced in Excerpt 6.

Excerpt 6

'Sooner or later, members of a cooperatively-run business MUST find a way to grow their maturity to a level that insists on and welcomes diversity of thought and belief, inclusion of multiple perspective and creative, cooperative problem-solving.

The attributive adjective 'cooperative' is used three times in this text-each time it refers to Citybikes. As Citybikes is, in fact, a worker-owned cooperative business, this is perhaps not 
remarkable; nevertheless, it provides further evidence of the identity which Citybikes establishes for itself. Though they champion Calvert's political identity, Citybikes' self-image, while it includes freedom ('diversity of thought and belief') and tolerance ('inclusion of multiple perspective’) as central characteristics, does not include being political. Citybikes’ displays their lack of political identity with their treatment of sexism and racism as the unacceptable personal stance of unacceptable persons ('Sexism, racism, and other forms of personal oppression have no place at Citybikes), rather than a social, political, and institutional force that always operates, and does not require its agents to share its views.

In Excerpt 7, the first sentence portrays Antifa's call for Calvert to stop engaging in antiSemitic and fascist organizing as an infringement on Calvert’s First Amendment rights, ('shutting down disparate voices), and one that is almost violently forceful ('harassment and intimidation'). The right to free speech is arguably revered as the foundation of American democracy and freedom; though only the state can violate the First Amendment, to portray an entity as attempting to infringe upon free speech is to identify that entity as deeply undemocratic and illiberal. Citybikes' goes on to cement its socially liberal position by using attributive adjectives to express the valuing of multiple voices as an intrinsic characteristic of its nature ('respectful, constructive dialog'). The two sentences together construct for Citybikes' identity as liberal and democratic, and provide Antifa with an identity in opposition to that..

\section{Excerpt 7}

'Shutting down disparate voices through harassment and intimidation does not serve any cause well. Our desire is to seek understanding through respectful, constructive dialog'. 
In Excerpt 7, Citybikes uses attributive adjectives (among other language choices) to identify themselves as liberal and tolerant, and to obliquely position those characteristics as democratic and themselves as legitimate members of leftist spaces. By implying that RCA doesn't share those value, it positions the organization as existing outside of those spaces. Citybikes, perhaps due to its apolitical identity, seems to be unaware of the existence of the left as a political space, not just a social one.

This ignorance is perhaps revealed in their use of attributive adjectives to explicitly challenge Antifa’s anti-fascist identity in Excerpt 8.

Excerpt 8

'Finally, we find it more than a little ironic that a self-labeled "antifascist" organization would resort to harassment and intimidation to achieve their ends.'

Citybikes’ lack of political identity becomes even clearer in the Excerpt 8. They question the veracity of the identity Antifa creates for itself ('self-labeled') by describing a tension ('more than a little ironic') between RCA's anti-fascist identity ('self-labeled "antifascist" organization') and their tactics, which suggests that, in Citybikes’ view, harassment and intimidation are the characteristics most central to a fascist identity; in fact, fascism is a political philosophy with values and goals separate from whatever tactics might be used to forward it. In Excerpt 7, they referred to Antifa's call for Calvert to end fascist organizing, and for Citybikes’ to hold him accountable should he fail to do so, as a free speech infringement; they referred to Antifa's tactics as harassment and intimidation. In this way, they place these tactics, and those who use them, in conflict with democratic spaces. Ultimately, Citybikes’ uses Rose City 
Antifa’s intolerance for fascist speech and organizing to assign to them an identity of narrowmindedness in order to relegate RCA firmly outside of leftist spaces.

By positioning Antifa as intolerant, and disapproving of the tactics Antifa used in their attempts to stop Calvert bringing fascist speakers and Holocaust deniers into our city, Citybikes betrays their view of RCA as the real danger.

Citybikes’ statement created identities and images of Calvert, Rose City Antifa, and Citybikes itself. In the statement, Calvert’s and Citybikes’ identities (tolerant, diverse, democratic) are in harmony, which aligns with their choice to stand in solidarity with Calvert. However, that solidarity is evidence of the great chasm between their self-image as sociallyand perhaps, as a result of their ties to Calvert, vaguely politically-left and their actions and words, which serve to provide a veneer of tolerance and respectability to a man who engages in fascist, white supremacist, and anti-Semitic organizing.

Through this Critical Discourse Analysis, I used linguistic feature analysis of adjectives, specifically attributive adjectives, to examine how identities are constructed. I found that both positive and negative identities can be crafted through the application of adjectives to subjects in the world. I also found that identity-crafting and conferring is a strategy that may be employed to refute a claim of problematic behavior without having to acknowledge, address, or engage with the behavior itself. In the texts examined in this analysis, the conferral of identity neatly sidesteps engagement with whether or not an organization or entity is undertaking or has undertaken distasteful or dangerous acts by pointing to positive personal attributes as evidence of 
the inherent goodness or badness of the organization in question. The behaviors and actions themselves are therefore rendered meaningless and erased.

Previously, I mentioned the assumption that underlies attempts to refute claims and evidence of oppression by creating and bestowing positive personal identities on those who engage in oppressive acts, including but not limited to speech acts; namely, that people's words and actions have no bearing on their identity. To the contrary, I think that any organization or figure that positions itself as a member of the leftist and/or anti-oppressive community must work to insure that both actions and words align with that positioning, and that failure to do so requires intervention by community members and people of conscience to put pressure on the entity or organization to correct that misalignment. If the organization demurs, the community must adjust the misalignment itself, perhaps by publicly re-positioning the entity in question in a way that more accurately reflects its political views, perhaps by pointing out where tension exists between the speech acts of an organization and the actions it undertakes until the organization brings itself into alignment. 


\section{Appendix A}

Regarding the Allerseelen/Waldteufel Show

The Variant would like to explain that it is our primary concern in this matter to maintain a Safer Space Policy. At this point no judgment as been made as to whether or not any of the bands involved with this show are indeed fascists, and we do not necessarily agree with the actions of Rose City Antifa in this case. Nonetheless, we decided it was best to cancel the show.

This decision came after days of discussions with multiple parties involved taking into consideration the nature of the Variant. We are a small community space that is dedicated to fostering creative and artistic collaborations, particularly within the anarchist, anti-authoritarian and radical community.

Although there is conflicting information that brings suspicion to the political intentions of Allerseelen, to our knowledge none of the bands lyrics or actions have been overtly fascist or violent, and most of the information and statements attributed to them are arguable. We were appreciative of the initial intervention of Rose City Antifa in alerting us of the potential conflict of interest and their intention to publish an article about the band. We were surprised by this information, and assured them we would look into the matter because it is not our intention to support oppression of any kind. They did not list the contact info of the Variant in their initial article, however it was made known in the days of phone calls that followed that if we went ahead with the show they would publicize our information effectively blacklisting the Variant and those involved with this space- presumably guilty by association as fascist enablers.

Regardless of this threat we had already decided that in order to retain the confidence of the our community, and make sure people feel safe coming here it was necessary to step back from hosting the show and avoid any confusion about our politics. We also became concerned about the potential of violent confrontation that may have arisen as a result of the show. 


\section{Appendix B}

This letter is being presented in response to the allegations leveled at Tim Calvert by the organization calling itself Rose City Antifa[scist] (RCA).

Tim Calvert was one of the people responsible for transforming Citybikes from a sole proprietorship into a worker-owned cooperative in 1990. Tim is well known in the Cooperative for his years of political organizing and for his political and social points of view on a wide range of topics, some of which appear quite controversial to the casual observer. The beauty of working in a cooperative business structure is that no one here gets away with being a casual observer for very long. Sooner or later, members of a cooperatively-run business MUST find a way to grow their maturity to a level that insists on and welcomes diversity of thought and belief, inclusion of multiple perspectives and creative, cooperative problem-solving.

Sexism, racism and other forms of personal oppression have no place at Citybikes. Tim has always respected the diversity of thought, belief and religious observance that is to be found here. We have never heard him say anything that could be construed as anti-Semitic, or really anti- anything else, for that matter. Several members of Citybikes' Workers Cooperative are of Jewish heritage and at least one is a religiously observant Jew. None of us has ever felt that Tim did not accept us for our heritage or religious practices.

The one thing we know Tim to be firmly against is any organization, institution or ideology that requires lockstep thought and action; we applaud this sort of thinking as the natural by-product of embracing a cooperative structure and learning to work with its many nuances, agreements and disagreements. We have found Tim's political discussions to be highly nuanced, mature and thoughtful, and indicative of the reality that the world is a complicated place in which to live. Shutting down disparate voices through harassment and intimidation does not serve any cause well. Our desire is to seek understanding through respectful, constructive dialog.

We would like to point out that the RCA's insistence that Citybikes vote Tim out of the Cooperative is, firstly, illegal. A person cannot be fired from his employment for his political, religious or philosophical views. Finally, we find it more than a little ironic that a self-labeled "antifascist" organization would resort to harassment and intimidation to achieve their ends.

We support Tim Calvert as a member of the Cooperative.

Sincerely,

The Board of Directors

Citybikes Workers' Cooperative 